\title{
PENGARUH EFIKASI DIRI DAN KOMUNIKASI INTERPERSONAL TERHADAP KINERJA PROFESIONAL PUSTAKAWAN
}

\author{
Farid Andriansyah Zakaria \\ Universitas Airlangga. \\ farid@staf.unair.ac.id
}

\begin{abstract}
ABSTRAK
Penelitian ini bertujuan untuk menganalisa pengaruh efikasi diri dan komunikasi interpersonal terhadap kinerja pustakawan. Penelitian ini menggunakan pendekatan kuantitatif dan dilakukan pada 30 orang pustakawan Perguruan Tinggi Negeri. Metode yang digunakan adalah metode survei dengan teknik analisis deskriptif dan verifikatif. Teknik pengumpulan data yaitu dengan kuesioner dengan menggunakan skala likert. Pengujian instrumen data dilakukan dengan uji validitas dan reliabilitas, sedangkan analisis data yang digunakan korelasi pearson product moment dan koefisien determinasi dan uji hipotesis dengan uji t. Berdasarkan hasil penelitian korelasi pearson product moment hubungan antara efikasi diri dengan kinerja profesional pustakawan termasuk kategori cukup signifikan dan bernilai positif. Berdasarkan uji t maka Ha diterima dan Ho ditolak, artinya ada pengaruh yang cukup signifikan antara efikasi diri terhadap kinerja pustakawan. Berdasarkan hasil korelasi pearson product moment hubungan antara komunikasi interpersonal dengan kinerja profesional pustakawan termasuk kategori cukup dan bernilai positif. Berdasarkan uji t maka Ha diterima dan Ho ditolak, artinya ada pengaruh yang cukup signifikan antara komunikasi interpersonal terhadap kinerja pustakawan. Berdasarkan Ujif didapatkan fhitung lebih besar dari pada F tabel, artinya efikasi diri dan komunikasi interpersonal secara simultan memiliki pengaruh positif pada kinerja profesional pustakawan dan mampu memberikan pengaruh positif pada pelayanan secara profesional dapat memberikan layanan prima dan mendapatkan kepercayaan kepada pemustakanya.
\end{abstract}

Kata kunci : efikasi diri, komunikasi interpersonal, kinerja, Pustakawan

\section{PENDAHULUAN}

Topik pertemuan ilmiah pustakawan yang sedang ramai diperbincangkan lebih banyak menitik beratkan pada Revolusi Industri 4.0, Society 5.0, Perkembangan teknologi informasi baik e-journal, e-books, literasi informasi, keterbukaan informasi, aplikasi dan perkembangannya perlu diimbangi dengan konsep kepribadian pustakawan. Meskipun konsep kepribadian merupakan konsep yang lama tetapi kepribadian merupakan syarat mutlak terwujudnya pustakawan yang profesional, berkepribadian unggul, humanis, dan inklusif. Humanis artinya memanusiakan manusia dan mengabdi kepada kepentingan sesama manusia. Sebagai garda terdepan yang memberikan pelayanan secara langsung kepada pemustakanya, Pustakawan dituntut untuk berkinerja dan profesional dalam menjalankan tugasnya. Menurut A.A Anwar Prabu Mangkunegara (2005:9) Kinerja merupakan hasil kerja secara kuantitas dan kualitas yang dapat dicapai oleh seorang pegawai dalam melaksanakan tugas sesuai dengan tanggung jawab yang diberikannya. Profesionalisme adalah suatu sikap atau keadaan dalam melaksanakan pekerjaan dengan memerlukan keahlian melalui pendidikan dan pelatihan tertentu dan dilakukan sebagai suatu pekerjaan yang menjadi sumber penghasilan (Sedarmiyati, 2004:157). 


\section{TINJAUAN PUSTAKA}

Adapun lima konsep profesionalisme dari Hall (1968) secara keseluruhan adalah sebagai berikut: 1. Afiliasi Komunitas (community affiliation) yaitu menggunakan ikatan profesi sebagai acuan, termasuk didalamnya organisasi formal dan kelompok-kelompok kolega informal sumber ide utama pekerjaan. Melalui ikatan profesi ini para profesional membangun kesadaran profesi. 2. Kebutuhan untuk mandiri (Autonomy demand) merupakan suatu pandangan bahwa seseorang yang profesional harus mampu membuat keputusan sendiri tanpa tekanan dari pihak lain (Pemerintah, klien, mereka yang bukan anggota profesi). Setiap adanya campur tangan (intervensi) yang datang dari luar, dianggap sebagai hambatan terhadap kemandirian secara profesional. Banyak yang menginginkan pekerjaan yang memberikan hakhak istimewa untuk membuat keputusan dan bekerja tanpa diawasi secara ketat. Rasa kemandirian dapat berasal dari kebebasan melakukan apa yang terbaik menurut karyawan yang bersangkutan dalam situasi khusus. Dalam pekerjaan yang terstruktur dan dikendalikan oleh manajemen secara ketat, akan sulit menciptakan tugas yang menimbulkan rasa kemandirian dalam tugas. 3. Keyakinan terhadap peraturan sendiri/profesi (belief self regulation) dimaksud bahwa yang paling berwenang dalam menilai pekerjaan profesional adalah rekan sesama profesi, bukan "orang luar" yang tidak mempunyai kompetensi dalam bidang ilmu dan pekerjaan mereka. 4. Dedikasi pada profesi (dedication) dicerminkan dari dedikasi profesional dengan menggunakan pengetahuan dan kecakapan yang dimiliki. Keteguhan untuk tetap melaksanakan pekerjaan meskipun imbalan ekstrinsik berkurang. Sikap ini merupakan ekspresi dari pencurahan diri yang total terhadap pekerjaan. Pekerjaan didefinisikan sebagai tujuan. Totalitas ini sudah menjadi komitmen pribadi, sehingga kompensasi utama yang diharapkan dari pekerjaan adalah kepuasan rohani dan setelah itu baru materi. 5. Kewajiban sosial (social obligation) merupakan pandangan tentang pentingnya profesi serta manfaat yang diperoleh baik oleh masyarakat maupun profesional karena adanya pekerjaan tersebut.

Ciri-ciri profesionalisme antara lain:1. Keinginan untuk selalu menampilkan perilaku yang dapat dijadikan sebagai rujukan yang baik. 2. Berusaha meningkatkan dan memelihara perilaku profesionalnya melalui perwujudan perilaku profesional. Perwujudan tersebut dilakukan melalui berbagai cara misalnya dari cara berpenampilan, cara berbicara, penggunaan bahasa, sikap tubuh badan, serta sikap hidupnya sehari-hari. 3. Keinginan untuk sentiasa mengejar berbagai kesempatan pengembangan profesional yang dapat meningkatkan dan memperbaiki kualitas pengetahuan dan keterampilannya.

Efikasi diri merupakan suatu keyakinan atau kepercayaan diri individu mengenai kemampuannya untuk mengorganisasi, melakukan suatu tugas, mencapai suatu tujuan, menghasilkan sesuatu dan mengimplementasi tindakan untuk mencapai kecakapan tertentu (Heppy \& Nur, 2012).

Keyakinan diri yang dimaksud di sini adalah efikasi diri, dimana efikasi diri merupakan keyakinan atau kepercayaan individu mengenai kemampuan dirinya untuk untuk mengorganisasi, melakukan suatu tugas, mencapai suatu tujuan, menghasilkan sesuatu dan mengimplementasi tindakan untuk menampilkan kecakapan tertentu (Bandura, 1997).

Salah satu faktor lain yang perludiperhatikan oleh pustakawan untuk meningkatkan profesionalisme pustakawan adalah komunikasi interpersonal. Manusia selalu memerlukan dan 
berjumpa dengan orang lain dalam kehidupannya. Agar bisa diterima dan beradaptasi dengan baik, individu harus berusaha menjalin hubungan dengan individu lain. Dalam situasi apapun termasuk dalam lingkungankerja, komunikasi interpersonal memegang peranan penting. Bagi individu, komunikasi interpersonal yang baik dapat menjadi faktor yang menentukan keberhasilan pustakawan. Individu juga mendapatkan dukungan sosial dari rekan sekerjanya, sehingga dapat mengurangi stres akibat tekanan pekerjaan. Hal tersebut dapat berdampak bagi produktivitas individu dan kepuasan kerja. Menurut Robbins (2007:22), Komunikasi interpersonal adalah: "Interaksi antara seseorang dengan orang lain dalam situasi kerja dan dalam organisasi sebagai motivasi untuk bekerjasama secara produktif, sehingga dicapai kepuasan ekonomi, psikologis dan sosial". Berdasarkan latar belakang di atas, peneliti tertarik untuk menguji hubungan antara efikasi diri, komunikasi interpersonal dan profesionalisme pustakawan.

\section{METODE PENELITIAN}

Penelitian ini menggunakan pendekatan kuantitatif dengan metode deskriptif eksplanatif, dimana penelitian ini digunakan untuk meneliti pada populasi/sampel tertentu, pengumpulan data menggunakan instrumen penelitian, data penelitian berupa angka-angka, analisis data bersifat kuantitatif/statistik, dengan tujuan untuk menguji hipotesis yang telah ditetapkan. Hasil akhir dari penelitian ini adalah gambaran mengenai hubungan sebab akibat yaitu pengaruh efikasi diri dan komunikasi interpersonal pada kinerja profesional pustakawan perguruan tinggi. Teknik pengambilan sampling yang digunakan dalam penelitian ini menggunakan kuisioner dengan skala likert melalui google form untuk mendapatkan informasi yang dibutuhkan, kerangka konsep berpikir yang peneliti ajukan sebagai berikut:

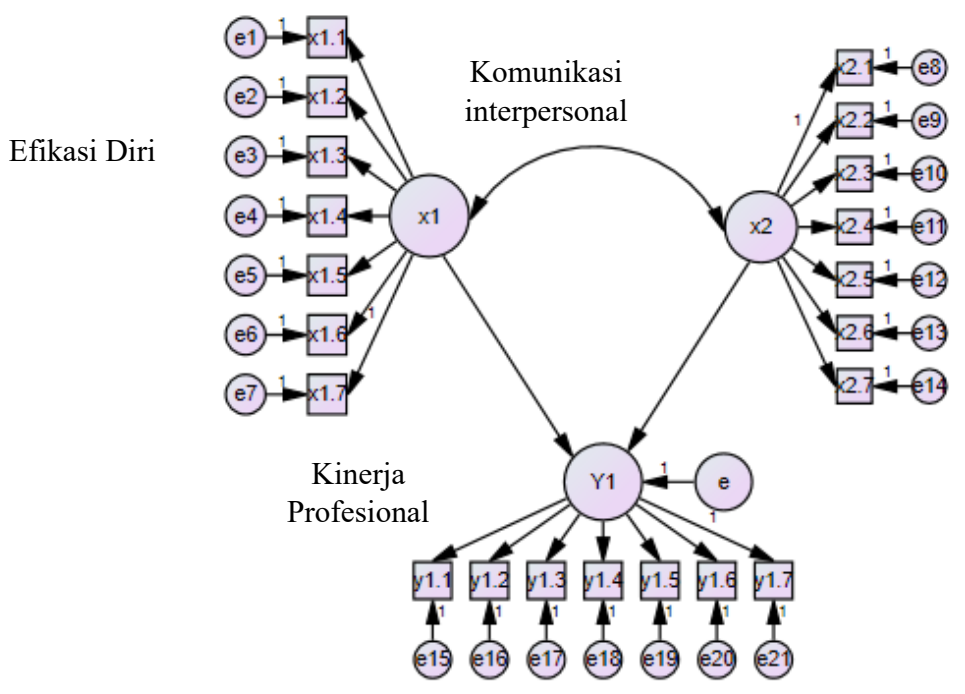

Gambar 1. Kerangka Konsep

Definisi operasional pada penelitian ini antara lain:

1. Efikasi diri yakni keyakinan/kepercayaan diri yang ada pada diri seseorang untuk mampu mengorganisir, melakukan suatu tugas, mencapai suatu tujuan, mengimplementasikan suatu tindakan untuk mencapai kecakapan tertentu. Indikator efikasi diri antara lain: 

a. Pengalaman yang menetap
b. Pengalaman yang dirasakan
c. Keadaan psikologis

2. Komunikasi interpersonal adalah komunikasi yang berlangsung dalam suatu tatap muka antara dua orang atau lebih, baik secara terorganisasi maupun pada kerumunan orang (Wiryanto, 2004). Indikator komunikasi interpersonal antara lain:
a. Keterbukaan
b. Empati
c. Dukungan
d. Kepositifan/Prilaku positif
e. Kesamaan

3. Kinerja yakni hasil kerja yang dapat dicapai oleh seseorang dalam melaksanakan tugas sesuai dengan tanggungjawab yang diberikan kepadanya. Indikator kinerja antara lain:
a. Kualitas
b. Kuantitas
c. Ketepatan waktu
d. Efektifitas
e. Kemandirian
f. Komitmen kerja

\section{HASIL DAN PEMBAHASAN}

Berdasarkan uji reliabilitas dan validitas untuk variabel X1 (Efikasi diri) didapatkan $\mathrm{r}$ hitung lebih besar dari $r$ tabeldan cronbach alfa 0,776 yang artinya lolos uji validitas dengan reliabilitas tinggi. Untuk variabel X2 (Komunikasi interpersonal) didapatkan $r$ hitung lebih besar dari $r$ tabel dan cronbach alfa 0,801 yang artinya lolos uji validitas dan uji reliabilitas dengan signifikansi tinggi. Untuk variabel $\mathrm{Y}$ (profesionalisme) didapatkan $\mathrm{r}$ hitung lebih besar dari $r$ tabel dan cronbach alfa 0,942 yang artinya lolos uji validitas dan uji reliabilitas dengan signifikansi tinggi. 
Tabel 1. Uji Validitas x1,x2,y

\begin{tabular}{|c|c|c|c|c|c|c|c|c|}
\hline \multicolumn{9}{|c|}{ Correlations } \\
\hline & & $\mathrm{x} 1.1$ & $\mathrm{x} 1.2$ & $x 1.3$ & $\mathrm{x} 1.4$ & $\mathrm{x} 1.5$ & $\mathrm{x} 1.6$ & $x 1.7$ \\
\hline \multirow[t]{3}{*}{$\mathrm{x} 1.1$} & Pearson Correlation & 1 & $.793^{\mathrm{N}}$ & $.674^{\kappa \times}$ & $.639^{\star \pi}$ & $.760^{\star n}$ & $.448^{\star}$ & $.364^{x}$ \\
\hline & Sig. (2-tailed) & & .000 & .000 & .000 & .000 & .013 & .048 \\
\hline & N & 30 & 30 & 30 & 30 & 30 & 30 & 30 \\
\hline \multirow[t]{3}{*}{$\mathrm{x} 1.2$} & Pearson Correlation & $.793^{* *}$ & 1 & $.793^{* x}$ & $.775^{\star *}$ & $.689^{* *}$ & $.589^{\star *}$ & $.472^{k \prime}$ \\
\hline & Sig. (2-tailed) & .000 & & .000 & .000 & .000 & .001 & .008 \\
\hline & $\mathrm{N}$ & 30 & 30 & 30 & 30 & 30 & 30 & 30 \\
\hline \multirow[t]{3}{*}{$\mathrm{x} 1.3$} & Pearson Correlation & $.674^{* x}$ & $.793^{\mathrm{x}}$ & 1 & $.762^{\star x}$ & $.760^{\star x}$ & $.560^{\star *}$ & $.579^{\star x}$ \\
\hline & Sig. (2-tailed) & .000 & .000 & & .000 & .000 & .001 & .001 \\
\hline & $\mathrm{N}$ & 30 & 30 & 30 & 30 & 30 & 30 & 30 \\
\hline \multirow[t]{3}{*}{$\mathrm{x} 1.4$} & Pearson Correlation & $.639^{\star *}$ & $.775^{\star \star}$ & $.762^{\star x}$ & 1 & $.743^{\star *}$ & $.633^{\star x}$ & $.654^{\mathrm{N}}$ \\
\hline & Sig. (2-tailed) & .000 & .000 & .000 & & .000 & .000 & .000 \\
\hline & $\mathrm{N}$ & 30 & 30 & 30 & 30 & 30 & 30 & 30 \\
\hline \multirow[t]{3}{*}{$\mathrm{x} 1.5$} & Pearson Correlation & $.760^{\star *}$ & $.689^{\mathrm{x}}$ & $.760^{\star *}$ & $.743^{\star *}$ & 1 & $.529^{\star x}$ & $.689^{\mathrm{N}}$ \\
\hline & Sig. (2-tailed) & .000 & .000 & .000 & .000 & & .003 & .000 \\
\hline & $\mathrm{N}$ & 30 & 30 & 30 & 30 & 30 & 30 & 30 \\
\hline \multirow[t]{3}{*}{$\mathrm{x} 1.6$} & Pearson Correlation & $.448^{*}$ & $.589^{\mathrm{x}}$ & $.560^{\mathrm{x}}$ & $.633^{\mathrm{x}}$ & $.529^{\star x}$ & 1 & $.699^{\mathrm{N}}$ \\
\hline & Sig. (2-tailed) & .013 & .001 & .001 & .000 & .003 & & .000 \\
\hline & $\mathrm{N}$ & 30 & 30 & 30 & 30 & 30 & 30 & 30 \\
\hline \multirow[t]{3}{*}{$\mathrm{x} 1.7$} & Pearson Correlation & $.364^{\pi}$ & $.472^{\mathrm{n}}$ & $.579^{* \pi}$ & $.654^{\pi \times}$ & $.689^{\star *}$ & $.699^{* *}$ & 1 \\
\hline & Sig. (2-tailed) & .048 & .008 & .001 & .000 & .000 & .000 & \\
\hline & $\mathrm{N}$ & 30 & 30 & 30 & 30 & 30 & 30 & 30 \\
\hline
\end{tabular}

\begin{tabular}{|c|c|c|c|c|c|c|c|c|}
\hline \multicolumn{9}{|c|}{ Correlations } \\
\hline & & $\times 2.1$ & $x 2.2$ & $\times 2.3$ & $\times 2.4$ & $\times 2.5$ & $\times 2.6$ & $\times 2.7$ \\
\hline \multirow[t]{3}{*}{$x 2.1$} & Pearson Correlation & 1 & $.802^{n \times}$ & $.764^{\times \times}$ & $.486^{\mathrm{kn}}$ & $.503^{\mathrm{x}}$ & $.683^{\mathrm{n}}$ & $.530^{\mathrm{k}}$ \\
\hline & Sig. (2-tailed) & & .000 & .000 & .006 & .005 & .000 & .003 \\
\hline & $\mathrm{N}$ & 30 & 30 & 30 & 30 & 30 & 30 & 30 \\
\hline \multirow[t]{3}{*}{$x 2.2$} & Pearson Correlation & $.802^{\kappa \star}$ & 1 & $.816^{\mathrm{kx}}$ & $.537^{\mathrm{N*}}$ & .318 & $.605^{n \times}$ & $.471^{\pi \times}$ \\
\hline & Sig. (2-tailed) & .000 & & .000 & .002 & .087 & .000 & .009 \\
\hline & $\mathrm{N}$ & 30 & 30 & 30 & 30 & 30 & 30 & 30 \\
\hline \multirow[t]{3}{*}{$x 2.3$} & Pearson Correlation & $.764^{\times ”}$ & $.816^{\mathrm{n}}$ & 1 & $.463^{x}$ & .303 & $.659^{\mathrm{N}}$ & $.439^{*}$ \\
\hline & Sig. (2-tailed) & .000 & .000 & & .010 & .104 & .000 & .015 \\
\hline & $\mathrm{N}$ & 30 & 30 & 30 & 30 & 30 & 30 & 30 \\
\hline \multirow[t]{3}{*}{$\times 2.4$} & Pearson Correlation & $.486^{* *}$ & $.537^{\mathrm{x}}$ & $.463^{x}$ & 1 & $.430^{\star}$ & $.646^{\mathrm{N}}$ & $.558^{\wedge \times}$ \\
\hline & Sig. (2-tailed) & .006 & .002 & .010 & & .018 & .000 & .001 \\
\hline & $\mathrm{N}$ & 30 & 30 & 30 & 30 & 30 & 30 & 30 \\
\hline \multirow[t]{3}{*}{$\times 2.5$} & Pearson Correlation & $.503^{\mathrm{kx}}$ & .318 & .303 & $.430^{*}$ & 1 & $.485^{\mathrm{N}}$ & $.371^{*}$ \\
\hline & Sig. (2-tailed) & .005 & .087 & .104 & .018 & & .007 & .044 \\
\hline & $\mathrm{N}$ & 30 & 30 & 30 & 30 & 30 & 30 & 30 \\
\hline \multirow[t]{3}{*}{$\times 2.6$} & Pearson Correlation & $.683^{\mathrm{k}}$ & $.605^{* *}$ & $.659^{\mathrm{k}}$ & $.646^{* *}$ & $.485^{\mathrm{k}}$ & 1 & $.493^{\mathrm{kn}}$ \\
\hline & Sig. (2-tailed) & .000 & .000 & .000 & .000 & .007 & & .006 \\
\hline & $\mathrm{N}$ & 30 & 30 & 30 & 30 & 30 & 30 & 30 \\
\hline \multirow[t]{3}{*}{$x 2.7$} & Pearson Correlation & $.530^{\mathrm{n}}$ & $.471^{\star \pi}$ & $.439^{\star}$ & $.558^{\mathrm{N}}$ & $.371^{\star}$ & $.493^{\mathrm{N}}$ & 1 \\
\hline & Sig. (2-tailed) & .003 & .009 & .015 & .001 & .044 & .006 & \\
\hline & $\mathrm{N}$ & 30 & 30 & 30 & 30 & 30 & 30 & 30 \\
\hline
\end{tabular}




\begin{tabular}{|c|c|c|c|c|c|c|c|c|}
\hline \multicolumn{9}{|c|}{ Correlations } \\
\hline & & y1.1 & $\mathrm{y} 1.2$ & $\mathrm{y} 1.3$ & $\mathrm{y} 1.4$ & y1.5 & y1.6 & $\mathrm{y} 1.7$ \\
\hline \multirow[t]{3}{*}{ y1.1 } & Pearson Correlation & 1 & $.463^{\text {*x }}$ & $.617^{\mathrm{m}}$ & $.463^{* *}$ & $.428^{*}$ & $.653^{\mathrm{kx}}$ & $.426^{x}$ \\
\hline & Sig. (2-tailed) & & .010 & .000 & .010 & .018 & .000 & .019 \\
\hline & $\mathrm{N}$ & 30 & 30 & 30 & 30 & 30 & 30 & 30 \\
\hline \multirow[t]{3}{*}{$\mathrm{y} 1.2$} & Pearson Correlation & $.463^{* *}$ & 1 & $.850^{* *}$ & $.400^{*}$ & $.853^{\mathrm{n}}$ & $.722^{n \times}$ & $.476^{m \prime}$ \\
\hline & Sig. (2-tailed) & .010 & & .000 & .029 & .000 & .000 & .008 \\
\hline & N & 30 & 30 & 30 & 30 & 30 & 30 & 30 \\
\hline \multirow[t]{3}{*}{ y1.3 } & Pearson Correlation & $.617^{\mathrm{kN}}$ & $.850^{\mathrm{k}}$ & 1 & $.550^{\mathrm{k}}$ & $.853^{\star \star}$ & $.722^{n \times}$ & $.476^{k \star}$ \\
\hline & Sig. (2-tailed) & .000 & .000 & & .002 & .000 & .000 & .008 \\
\hline & $\mathrm{N}$ & 30 & 30 & 30 & 30 & 30 & 30 & 30 \\
\hline \multirow[t]{3}{*}{ y1.4 } & Pearson Correlation & $.463^{\mathrm{N}}$ & $.400^{\star}$ & $.550^{\mathrm{N}}$ & 1 & $.533^{\mathrm{Nx}}$ & $.577^{\mathrm{N}}$ & .333 \\
\hline & Sig. (2-tailed) & .010 & .029 & .002 & & .002 & .001 & .072 \\
\hline & $\mathrm{N}$ & 30 & 30 & 30 & 30 & 30 & 30 & 30 \\
\hline \multirow[t]{3}{*}{ y1.5 } & Pearson Correlation & $.428^{\star}$ & $.853^{\mathrm{kn}}$ & $.853^{\mathrm{N}}$ & $.533^{\mathrm{k}}$ & 1 & $.739^{* *}$ & $.527^{\mathrm{xm}}$ \\
\hline & Sig. (2-tailed) & .018 & .000 & .000 & .002 & & .000 & .003 \\
\hline & $\mathrm{N}$ & 30 & 30 & 30 & 30 & 30 & 30 & 30 \\
\hline \multirow[t]{3}{*}{ y1.6 } & Pearson Correlation & $.653^{* *}$ & $.722^{\mathrm{N}}$ & $.722^{\mathrm{N}}$ & $.577^{\wedge \times}$ & $.739^{\star x}$ & 1 & $.714^{\mathrm{N}}$ \\
\hline & Sig. (2-tailed) & .000 & .000 & .000 & .001 & .000 & & .000 \\
\hline & N & 30 & 30 & 30 & 30 & 30 & 30 & 30 \\
\hline \multirow[t]{3}{*}{ y1.7 } & Pearson Correlation & $.426^{n}$ & $.476^{\mathrm{kn}}$ & $.476^{\mathrm{m}}$ & .333 & $.527^{\star \star}$ & $.714^{n \times}$ & 1 \\
\hline & Sig. (2-tailed) & .019 & .008 & .008 & .072 & .003 & .000 & \\
\hline & $\mathrm{N}$ & 30 & 30 & 30 & 30 & 30 & 30 & 30 \\
\hline
\end{tabular}

Tabel 2. Uji Reliabilitas X1,X2,Y

\begin{tabular}{|c|c|c|c|c|c|}
\hline \multicolumn{6}{|c|}{ Item-Total Statistics } \\
\hline & $\begin{array}{l}\text { Scale Mean if } \\
\text { Item Deleted }\end{array}$ & $\begin{array}{c}\text { Scale } \\
\text { Variance if } \\
\text { Item Deleted }\end{array}$ & $\begin{array}{l}\text { Corrected } \\
\text { Item-Total } \\
\text { Correlation }\end{array}$ & $\begin{array}{l}\text { Squared } \\
\text { Multiple } \\
\text { Correlation }\end{array}$ & $\begin{array}{c}\text { Cronbach's } \\
\text { Alpha if Item } \\
\text { Deleted }\end{array}$ \\
\hline$\times 2.1$ & 27.85 & 8.816 & .745 & .921 & .782 \\
\hline$\times 2.2$ & 27.95 & 8.775 & .728 & .820 & .784 \\
\hline$\times 2.3$ & 27.96 & 8.645 & .743 & .764 & .781 \\
\hline$\times 2.4$ & 27.97 & 8.272 & .737 & .756 & .780 \\
\hline$\times 2.5$ & 27.83 & 9.233 & .777 & .951 & .785 \\
\hline$\times 2.6$ & 27.84 & 10.338 & .307 & .477 & .851 \\
\hline$\times 2.7$ & 27.84 & 10.802 & .172 & .446 & .875 \\
\hline
\end{tabular}




\begin{tabular}{|c|c|c|c|c|c|}
\hline \multicolumn{6}{|c|}{ Item-Total Statistics } \\
\hline & $\begin{array}{l}\text { Scale Mean if } \\
\text { Item Deleted }\end{array}$ & $\begin{array}{c}\text { Scale } \\
\text { Variance if } \\
\text { Item Deleted }\end{array}$ & $\begin{array}{l}\text { Corrected } \\
\text { Item-Total } \\
\text { Correlation }\end{array}$ & $\begin{array}{l}\text { Squared } \\
\text { Multiple } \\
\text { Correlation }\end{array}$ & $\begin{array}{l}\text { Cronbach's } \\
\text { Alpha if Item } \\
\text { Deleted }\end{array}$ \\
\hline y1t & 27.31 & 12.559 & .927 & . & .960 \\
\hline y2t & 27.44 & 12.633 & .778 & . & .972 \\
\hline y3t & 27.31 & 12.559 & .927 & . & .960 \\
\hline$y 4 t$ & 27.31 & 12.559 & .927 & . & .960 \\
\hline y5t & 27.44 & 12.633 & .778 & . & .972 \\
\hline y6t & 27.31 & 12.559 & .927 & . & .960 \\
\hline$y 7 t$ & 27.34 & 12.449 & .979 & . & .957 \\
\hline
\end{tabular}

Tabel 3. Uji Normalitas

\begin{tabular}{|c|c|c|}
\hline \multicolumn{3}{|c|}{ One-Sample Kolmogorov-Smirnov Test } \\
\hline & & $\begin{array}{l}\text { Unstandardiz } \\
\text { ed Residual }\end{array}$ \\
\hline N & & 30 \\
\hline \multirow[t]{2}{*}{ Normal Parameters ${ }^{a, b}$} & Mean & .0000000 \\
\hline & Std. Deviation & 1.88055632 \\
\hline \multirow[t]{3}{*}{ Most Extreme Differences } & Absolute & .161 \\
\hline & Positive & .105 \\
\hline & Negative & -.161 \\
\hline Test Statistic & & .161 \\
\hline Asymp. Sig. (2-tailed) & & $.045^{\mathrm{c}}$ \\
\hline \multicolumn{3}{|c|}{ a. Test distribution is Normal. } \\
\hline \multicolumn{3}{|l|}{ b. Calculated from data. } \\
\hline \multicolumn{3}{|c|}{ c. Lilliefors Significance Correction. } \\
\hline
\end{tabular}

Nilai residual berdistribusi normal karena $0.45<0.05$ seperti pada gambar diatas

Table 4. Uji Multikolinieritas hubungan korelasi antara efikasi diri dengan komunikasi interpersonal

\begin{tabular}{|c|c|c|c|c|c|c|c|c|}
\hline \multicolumn{9}{|c|}{ Coefficients $^{a}$} \\
\hline & & \multicolumn{2}{|c|}{ Unstandardized Coefficients } & \multirow{2}{*}{$\begin{array}{c}\text { Standardized } \\
\text { Coefficients } \\
\text { Beta }\end{array}$} & \multirow[b]{2}{*}{$\mathrm{t}$} & \multirow[b]{2}{*}{ Sig. } & \multicolumn{2}{|c|}{ Collinearity Statistics } \\
\hline \multicolumn{2}{|c|}{ Model } & $\mathrm{B}$ & Std. Error & & & & Tolerance & VIF \\
\hline \multirow[t]{3}{*}{1} & (Constant) & 2.279 & 3.221 & & .708 & .481 & & \\
\hline & $\mathrm{x} 1 . \mathrm{t}$ & .376 & .111 & .307 & 3.389 & .001 & .666 & 1.502 \\
\hline & $x 2 . t$ & .544 & .107 & .462 & 5.111 & .000 & .666 & 1.502 \\
\hline
\end{tabular}


Tabel 5. Uji Heterosklereditas

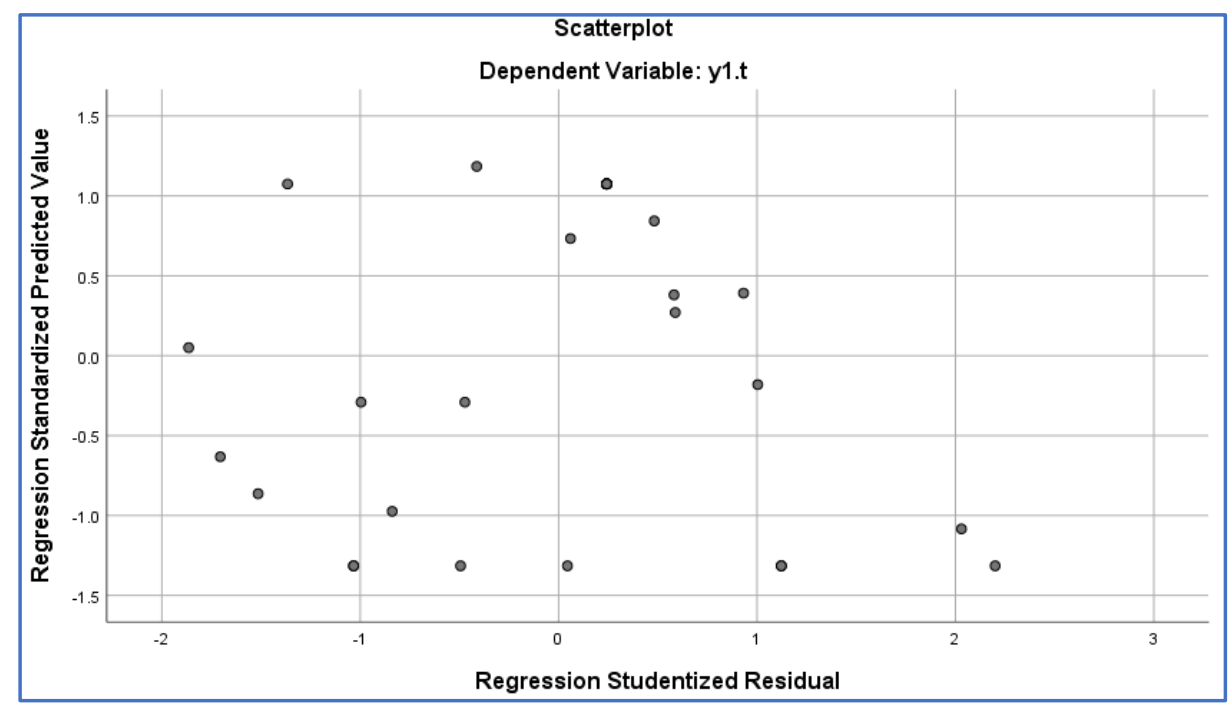

Uji F (Untuk mengetahui pengaruh secara bersama-sama (efikasi diri, komunikasi interpersonal) terhadap kinerja profesional)

Tabel 6. Uji F

\begin{tabular}{|c|c|c|c|c|c|c|}
\hline \multicolumn{7}{|c|}{ ANOVA $^{a}$} \\
\hline \multicolumn{2}{|c|}{ Model } & $\begin{array}{l}\text { Sum of } \\
\text { Squares }\end{array}$ & df & Mean Square & $\mathrm{F}$ & Sig. \\
\hline \multirow[t]{3}{*}{1} & Regression & 108.908 & 2 & 54.454 & 14.336 & $.000^{\mathrm{b}}$ \\
\hline & Residual & 102.558 & 27 & 3.798 & & \\
\hline & Total & 211.467 & 29 & & & \\
\hline \multicolumn{7}{|c|}{ a. Dependent Variable: y1.t } \\
\hline \multicolumn{7}{|c|}{ b. Predictors: (Constant) $\times 2 . t, \times 1 . t$} \\
\hline
\end{tabular}

Kriteria pengambilan keputusan terhadap uji f, adalah sebagai berikut :

a. Jika Fhitung $<$ Ftabel atau sig F $>$ alfa 5\%, Ho diterima, H1 ditolak

b. Jika Fthitung $>$ Ftabel atau sig $\mathrm{F}<$ alfa 5\%, Ho ditolak, H1 diterima

Rumus yang digunakan untuk melihat $\mathrm{f}$ tabel adalah df $1=\mathrm{k}-1$, df $2=\mathrm{n}-\mathrm{k}$ dengan taraf signifikan 5\%, dimana $\mathrm{k}$ adalah jumlah variabel (bebas + terikat) dan $\mathrm{n}$ adalah jumlah observasi/sampel pembentuk regresi. Maka df $1=3-1=2$ sedangkan df $2=30-3=27$.

Berdasarkan gambar diatas menunjukkan hasil bahwa Fhitung 14,336; > Ftabel 3,354 Sedangkan probabilitas signifikan $\mathrm{F}=0,000<\alpha=0,05$, yang berarti $\mathrm{H} 1$ diterima. Ini berarti bahwa variabel independen self eficacy dan komunikasi interpersonal secara simultan berpengaruh terhadap profesionalisme. 
Uji T (Pengaruh self eficacy dan komunikasi interpersonal terhadap profesionalisme)

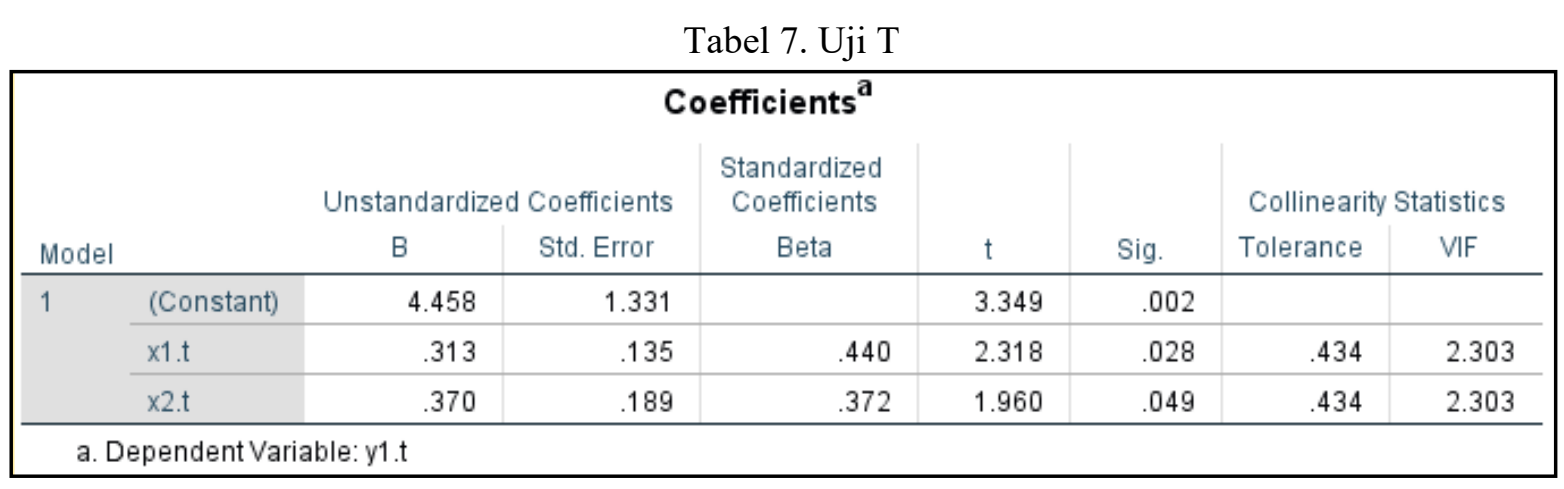

Uji Parsial atau uji t pada dasarnya menunjukkan seberapa jauh pengaruh satu variabel independen secara individual dalam menerangkan variasi variabel terkait dengan tingkat kepercayaan 95\% dan taraf kesalahan $\alpha 5 \%$, dengan uji 2 pihak dan df $=n-k$. Dimana, $n$ : jumlah sampel dan $\mathrm{k}$ : jumlah variabel.

Kriteria pengambilan keputusan terhadap uji t, adalah sebagai berikut :

a. Jika $\mathrm{T}$ hitung $<$ Ttabel atau sig $\mathrm{T}>$ alfa 5\%, Ho diterima, $\mathrm{H} 1$ ditolak

b. Jika $\mathrm{T}$ hitung $>$ Ttabel atau sig $\mathrm{T}<$ alfa $5 \%$, Ho ditolak, $\mathrm{H} 1$ diterima

Pada gambar diatas, uji statistik t diperoleh, sebagai berikut :

a Variabel self eficacy (X1). t hitung sebesar 3,13 sedangkan $t$ tabel sebesar 1,703 dan signifikan sebesar 0,001 , sehingga $\mathrm{t}$ hitung 3,13> t tabel 1,703 dan signifikan $0,028<0,05$, maka Ho diterima dan $\mathrm{H} 1$ ditolak, yang menyatakan efikasi diri secara parsial berpengaruh signifikan terhadap kinerja profesional pustakawan. Hal ini sejalan dengan penelitian (Disiana, 2019) yang menyatakan efikasi diri memiliki pengaruh positif terhadap kinerja pegawai sekretariat dan humas PT. PDAM Surya Sembada.

b Variabel komunikasi interpersonal (X2). t hitung sebesar 3,707 sedangkan t tabel sebesar 1,703 dan signifikan sebesar 1,703, sehingga thitung 3,707>t tabel 1,703 dan signifikan $0,049<0,05$, maka H1 diterima dan Ho ditolak, yang menyatakan komunikasi interpersonal secara parsial pada kinerja profesional. Hal ini sejalan dengan penelitian (Gumay dan Hermani, 2018) yang menyatakan komunikasi interpersonal memiliki pengaruh positif dan signifikan terhadap kinerja karyawan PT. Euro Management Indonesia.

\section{Hasil Uji Koefisien Determinasi ( R2 )}

Koefisien determinasi digunakan untuk menguji goodness-fit dari model regresi yang dapat lihat dari nilai R Square. Untuk mengetahui variabel profesionalisme yang dipengaruhi variabel efikasi diri dan komunikasi interpersonal dapat dilihat melalui besarnya koefisien determinasi. 
Tabel 8. R square

\begin{tabular}{|c|c|c|c|c|c|c|c|c|c|}
\hline \multicolumn{10}{|c|}{ Model Summary } \\
\hline \multirow[b]{2}{*}{ Model } & \multirow[b]{2}{*}{$\mathrm{R}$} & \multirow[b]{2}{*}{ R Square } & \multirow[b]{2}{*}{$\begin{array}{l}\text { Adjusted R } \\
\text { Square }\end{array}$} & \multirow[b]{2}{*}{$\begin{array}{l}\text { Std. Error of } \\
\text { the Estimate }\end{array}$} & \multicolumn{5}{|c|}{ Change Statistics } \\
\hline & & & & & $\begin{array}{c}\text { R Square } \\
\text { Change }\end{array}$ & F Change & df1 & df2 & $\begin{array}{l}\text { Sig. F } \\
\text { Change }\end{array}$ \\
\hline 1 & $.760^{\mathrm{a}}$ & .578 & .547 & 1.56257 & .578 & 18.480 & 2 & 27 & .000 \\
\hline \multicolumn{10}{|c|}{ a. Predictors: (Constant), x2.t, x1.t } \\
\hline
\end{tabular}

Hasil perhitungan nilai R sebesar 0,760 sebagai nilai korelasi berganda artinyaefikasi diri dan komunikasi interpersonal memiliki hubungan dengan kinerja profesional pustakawan. Nilai Adjusted R Square adalah 0,578 yang berarti 57,8\% dalam kinerja dapat dijelaskan oleh kedua variabel independen efikasi diridan komunikasi interpersonal sedangkan sisanya yaitu $42,2 \%$ dijelaskan oleh variabel lain yang tidak diikutsertakan dalam penelitian ini, seperti pada ketrampilan, pengetahuan, kepemimpinan, budaya organisasi, kepuasan kerja, integritas, dan komitmen.

\section{PENUTUP \\ KESIMPULAN}

Berdasarkan hasil analisa data dan pembahasan yang telah dilakukan, maka didapatkan kesimpulan dari penelitian yaitu "ada pengaruh self eficacy dan komunikasi interpersonal dengan kinerja profesional pustakawan”. Tingkat hubungan yang terjadi antara variabel efikasi diri terhadap profesionalisme cukup, arah korelasi bersifat positif. Tingkat hubungan yang terjadi antara variabel komunikasi interpersonal terhadap kinerja profesional cukup kuat, arah korelasi bersifat positif.

\section{SARAN}

Saran untuk penelitian selanjutnya diharapkan lebih memperhatikan faktor-faktor lain yang mungkin mempengaruhi hubungan antara kedua variabel, misalnya faktor eksternal dari subyek, seperti lingkungan kerja fisik/non fisik, budaya organisasi, kepemimpinan, dll. Faktor internal dari subyek seperti emosi, intelektual, motivasi, komitmen, kepuasan kerja, sharingknowledge dan kemampuan problem solving. Disamping itu subyek dalam penelitian juga membutuhkan variasi agar dapat mengembangkan pengetahuan tentang efikasi diri maupun komunikasi interpersonal 


\section{DAFTAR PUSTAKA}

A.A Anwar Prabu Mangkunegara. (2005). Manajemen Sumber daya Manusia Perusahaan. Bandung : PT Remaja Rosdakarya

Bandura, A. (1997). Efikasi diri: the Exercise of Control. New York:Freeman.

Desiana, 2019. Pengaruh Efikasi Diri Terhadap Kinerja Karyawan Melalui Inovasi Sebagai Variabel Intervening (Studi Pada Divisi Sekretariat Dan Humas Pdam Surya Sembada Kota Surabaya). Jurnal Jurnal Ilmu Manajemen 7(2) https://doi.org/10.14710/jab.v7i2.22691

Dian Wisnuwardhani dan Sri Fatmawati Mashoedi. 2012. Komunikasi interpersonal. Jakarta: Salemba Humanika

Gumay \& Hermani, 2018. Pengaruh Komunikasi Interpersonal dan Lingkungan Kerja Terhadap Kinerja Karyawan PT. Euro Management Indonesia . Jurnal Administrasi dan Bisnis.https://doi.org/10.14710/jab.v7i2.22691

Hall, R. H. (1968) Professionalization and Bureaucratization. American Sociological Review, $33,92-104$.

Hepy, Nur Ainy, 2012 Hubungan antara Efikasi diri dengan Kreativitas Siswa SMK. Jurnal Psikologi Klinis dan Kesehatan Mental

Robbins SP. 2007 Perilaku Organisasi, Jakarta: Salemba Empat Hal. 22

Sedarmayanti. (2004), Sumber Daya Manusia dan Produktivitas Kerja. Bandung: Mandar Maju

Wiryanto. 2004. Pengantar Ilmu Komunikasi. Jakarta: PT. Gramedia Widiasarana Indonesia. 